\title{
Distribution of Fecal Indicator Bacteria along the Malibu, California, Coastline
}

Each year, over 550 million people visit California's public beaches. To protect beach-goers from exposure to waterborne disease, California state law requires water-quality monitoring for fecal indicator bacteria (FIB), such as enterococci and Escherichia coli (E. coli), at beaches having more than 50,000 yearly visitors. FIB are used to assess the microbiological quality of water because, although not typically disease causing, they are correlated with the occurrence of certain waterborne diseases. Tests show that FIB concentrations occasionally exceed U.S. Environmental Protection Agency (USEPA) public health standards for recreational water in Malibu Lagoon and at several Malibu beaches (Regional Water Quality Control Board, 2009).

Scientists from the U.S. Geological Survey's (USGS) California Water Science Center are doing a study to identify the distribution and sources of FIB in coastal Malibu waters (fig. 1). The study methods were similar to those used in a study of FIB contamination on beaches in the Santa Barbara, California, area (Izbicki and others, 2009). This report describes the study approach and presents preliminary results used to evaluate the distribution and source of FIB in the Malibu area. Results of this study will help decision-makers address human health issues associated with FIB contamination in Malibu, and the methods used in this study can be used in other coastal areas affected by FIB contamination.

\section{Potential Sources of FIB}

There are several potential sources of FIB to Malibu Lagoon, and the nearby coastline, including:

- Effluent from commercial and residential onsite sewage-treatment systems that may enter the lagoon or near-shore ocean water through the groundwater system.

U.S. Department of the Interior U.S. Geological Survey

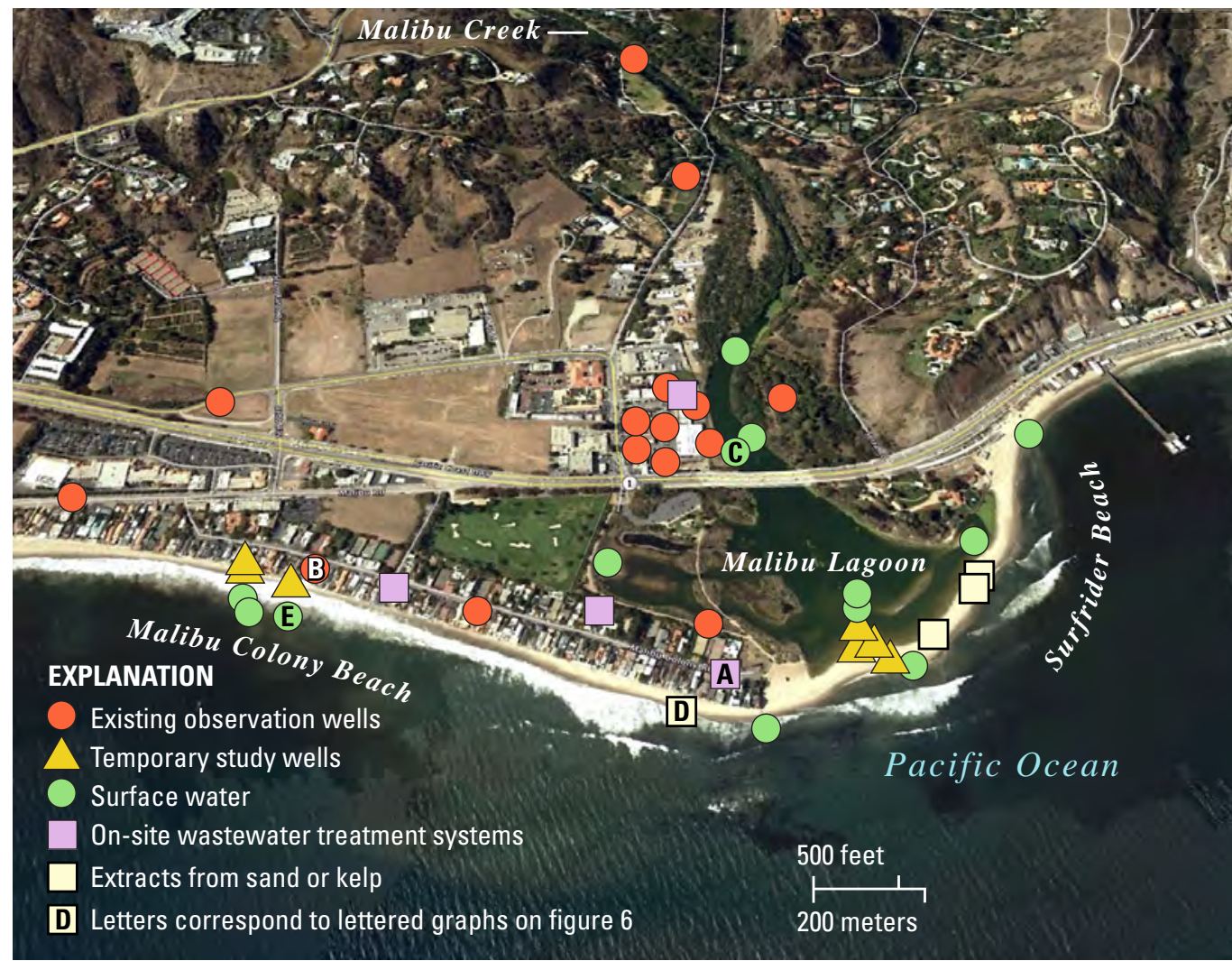

Figure 1. Selected sample locations, Malibu, California.

- Discharge or runoff from commercial and residential developments into Malibu Creek and Malibu Lagoon.

- Bird and wildlife feces, either deposited directly into the lagoon or onto beaches, or washed into these areas by tides and storms.

Determining the source of bacterial contamination is complicated in this hydrologically complex coastal setting. Some important factors affecting the hydrologic system include (1) rising and falling tides that continually affect water flowing into or out of the system; (2) groundwater levels that fluctuate seasonally, causing changes in groundwater flow; and, (3) a sand berm that develops

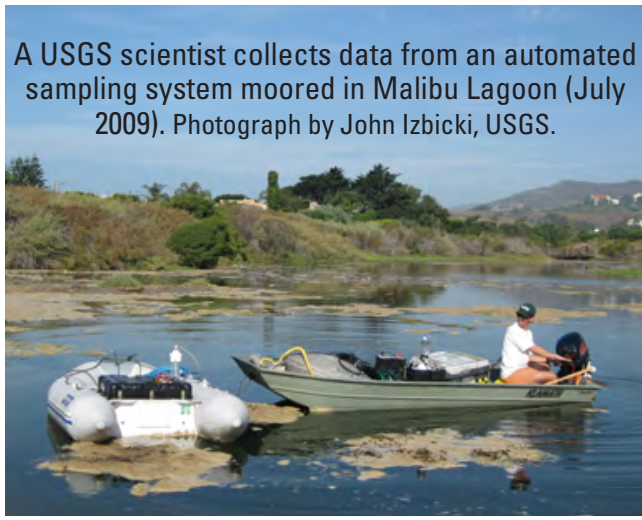
during dry weather, and that isolates the Malibu lagoon from ocean tides, creating conditions where bacteria might survive over long periods of time, and periodically flourish, especially during the summer months when water temperatures in the lagoon are warm.

8 Printed on recycled paper
Open-File Report 2011-1091 May 2011 


\section{Overview of Sample Collection and FIB Concentrations}

More than 450 FIB samples were collected from wells, Malibu Creek, Malibu Lagoon and the near-shore ocean (fig. 1) as part of this study. Samples from within onsite wastewater treatment systems, groundwater, and surface water including Malibu Creek, Malibu Lagoon, and near-shore ocean sites (Surfrider Beach and Malibu Colony beach) were analyzed for enterococci, E. coli, and total coliforms, in addition to field parameters and water chemistry. Most samples were collected during the dry season (July 2009) and at the end of rainy season (April 2010). FIB concentrations and most other data collected as part of this study are publicly available in U.S. Geological Survey's online database, NWIS (National Water Information System), at http:// waterdata.usgs.gov/nwis. Data not available online can be obtained by contacting the San Diego Office of the California Water Science Center.

Enterococci were found at concentrations as high as 242,000 most probable number per 100 milliliters (MPN per $100 \mathrm{ml}$ ) in samples collected from within onsite wastewater treatment systems (fig. 2). Enterococci concentrations exceeded the U.S. Environmental Protection Agency (USEPA) single-sample standand for enterococcus of $104 \mathrm{MPN}$ per 100 $\mathrm{ml}$ in marine recreational water in more than 57 percent of the samples collected from the Malibu Lagoon; in contrast, the enterococci concentrations exceeded USEPA standards in only 12 percent of the samples collected from Surfrider Beach, and 7 percent of samples from Malibu Colony Beach (fig. 2). Groundwater samples had the lowest concentrations, usually less than the detection limit of 1 MPN per $100 \mathrm{ml}$, during both the dry and wet season (fig. 2). The distribution of total coliform and $E$. coli bacteria results were similar to enterococcus results.

Water carrying FIB from onsite treatment systems must pass through the groundwater system before reaching the lagoon or near-shore ocean. Interpretation of the low enterococci concentrations, generally less than the detection limit, in groundwater samples suggests that FIB are not moving from the onsite wastewater treatment systems through the groundwater system.

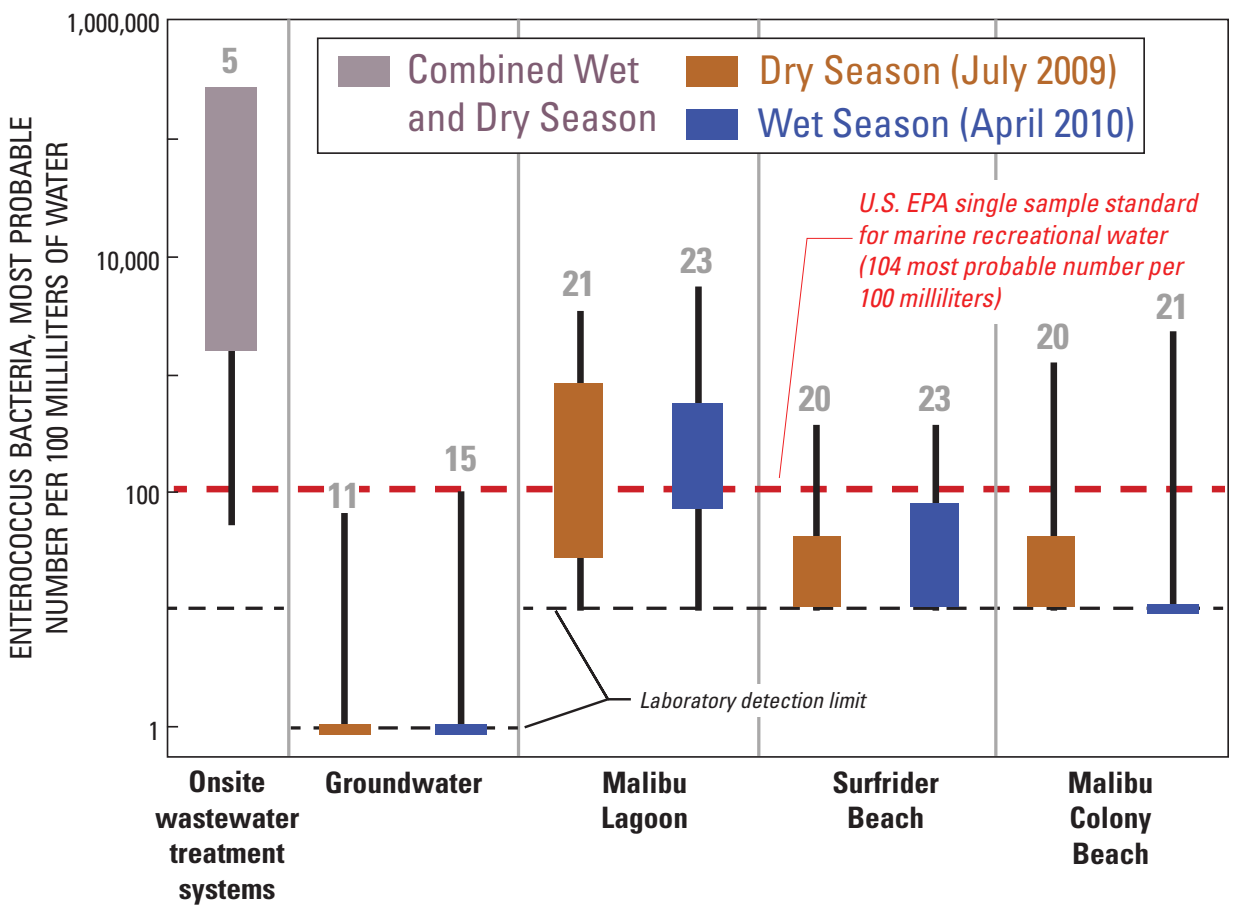

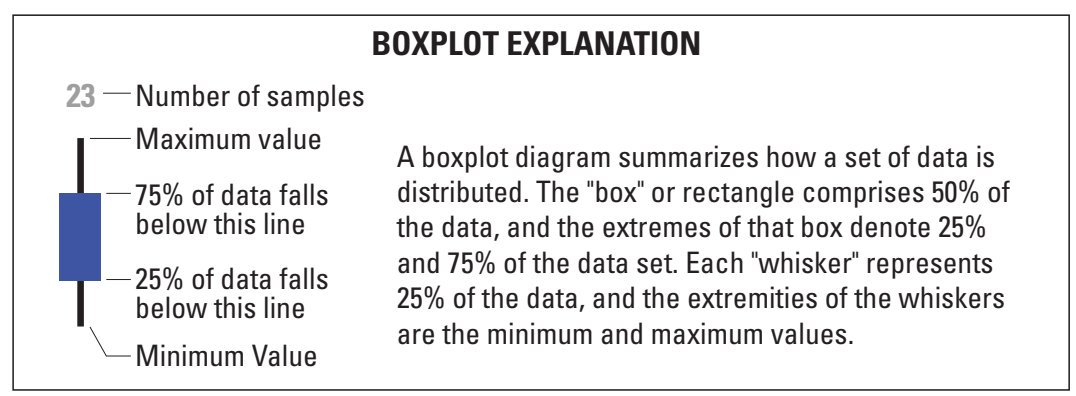

Figure 2. Selected enterococcus sampling results from onsite wastewater treatment systems, groundwater, Malibu Lagoon, and near-shore ocean, Malibu, California, 2009-2010.

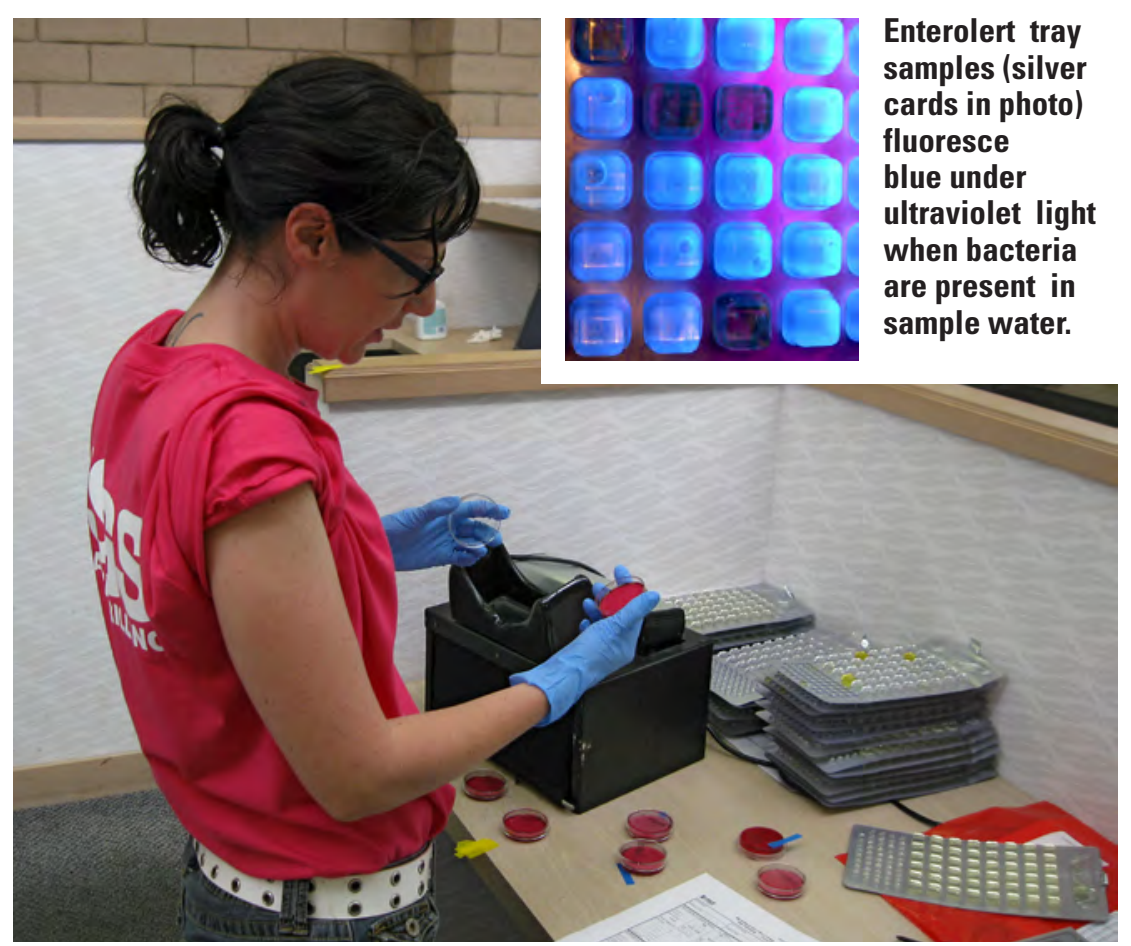

USGS hydrologist counts fecal indicator bacteria (FIB) colonies in samples (red petri dishes) in onsite field laboratory. Photograph by Carmen Burton, USGS, July 2009. 


\section{Seasonal and Tidal Influences on FIB Concentrations}

FIB concentrations vary seasonally and with daily tidal cycles. Samples were collected for 7 days at high, low, mid-high, and mid-low tides from Malibu Lagoon and near-shore ocean sites during the July 2009 dry season, and the April 2010 wet season. Additional samples were collected hourly from the near-shore ocean during a falling tidal cycle (from high to low tide) to assess FIB contributions associated with groundwater discharge.

Enterococci concentrations in Malibu Lagoon commonly exceeded the USEPA single sample standard for marine recreational water during the July (dry season) and April (wet season) sample periods (fig. $3 A$ and $C$ ). Enterococci concentrations decreased during the July sampling period as high tides and large waves caused ocean water to flow over the berm into the lagoon (fig. 3A). During this time, enterococci concentrations decreased to low values during the mid-afternoon, possibly as a result of photoinactivation by ultraviolet radiation in sunlight. In contrast, during the April sampling period, enterococci concentrations in the lagoon varied with the daily tidal cycles, as ocean water having low FIB concentrations entered the lagoon during high tide and water having high FIB concentrations exited the lagoon during low tide 6 hours later.

Enterococci concentrations were lower at Surfrider Beach and Malibu Colony Beach than in Malibu Lagoon (fig. $3 B, D, E$, and $F$ ). In general, enterococci concentrations were higher at Surfrider Beach than at Malibu Colony Beach, especially during low tide in April when water from the lagoon discharged directly to the ocean near Surfrider Beach (fig. 3C). Enterococcus concentrations at Malibu Colony Beach were higher at high tide in the summer than at low tide when groundwater discharge was greater.

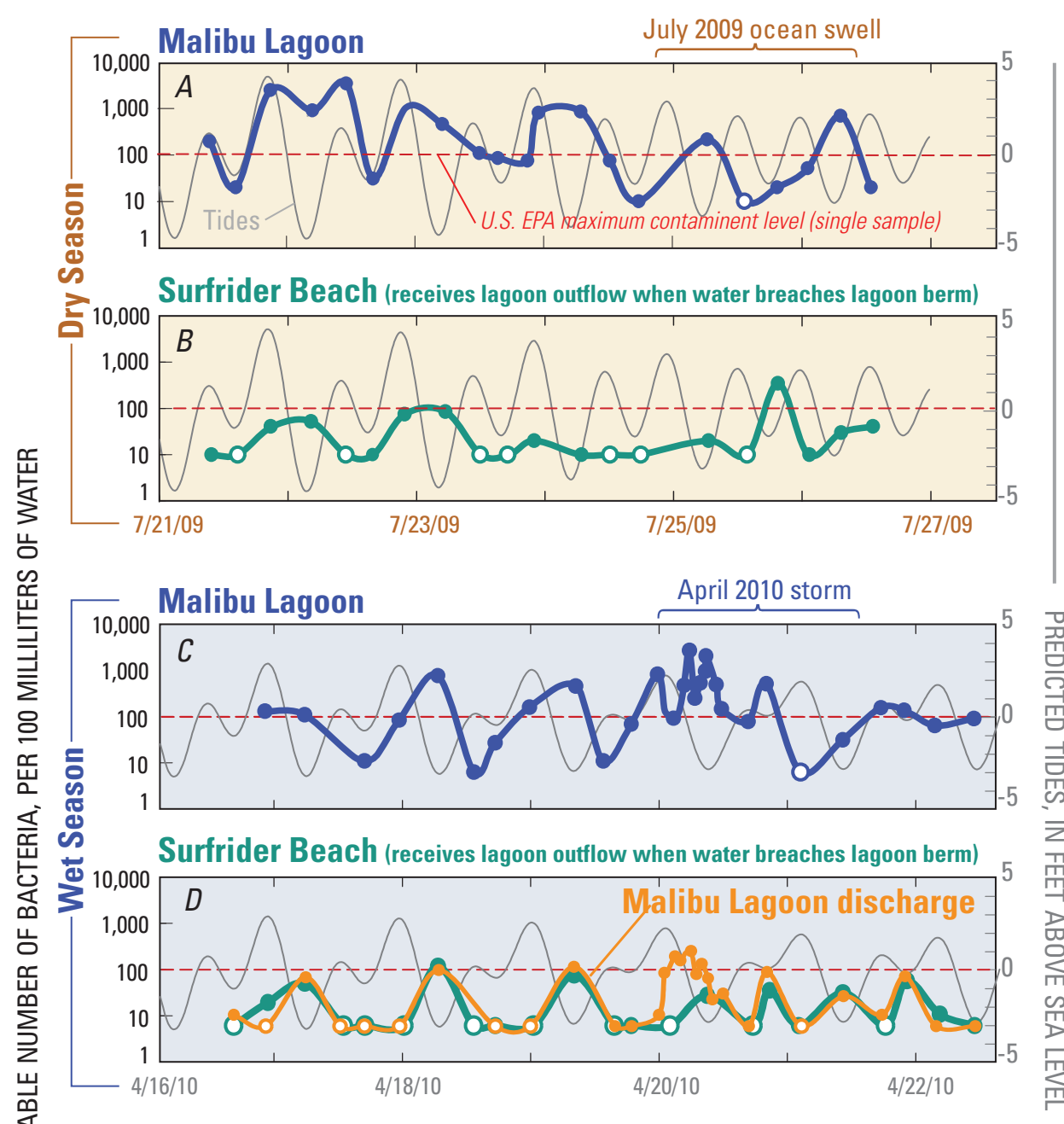

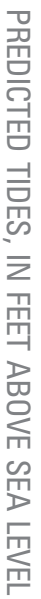
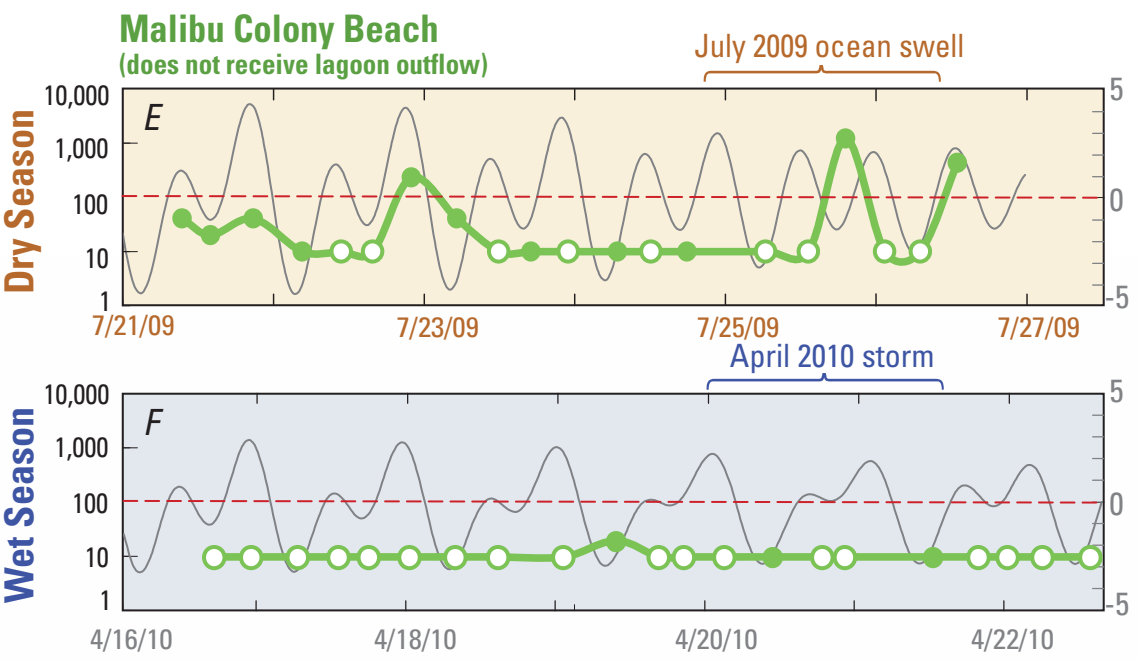

Open circles denote less than indicated value.

Figure 3. Enterococci concentrations in Malibu Lagoon, Surfrider Beach, and Malibu Colony Beach, Malibu, California, July 2009 (dry season) and April 2010 (wet season). 


\section{Identifying Wastewater and Groundwater Discharge}

The Malibu area utilizes onsite wastewater treatment systems to treat domestic and commercial wastewater. These systems include conventional septic-tank systems and more advanced treatment systems that may utilize biological media, oxidation, disinfection, or other technology. High FIB concentrations in Malibu Lagoon and the nearshore ocean have been attributed by the RWQCB (2009) to discharges from onsite wastewater treatment systems. Isotopic data were collected as part of this study to determine if samples from wells contained wastewater and to evaluate discharge from the groundwater system to Malibu Lagoon and to the near-shore ocean.

Naturally occurring stable isotopes of oxygen and hydrogen in the water molecule (oxygen-18 and deuterium, respectively) were used to determine the percentage of wastewater in groundwater samples. This technique works because all the water used for public supply that subsequently becomes wastewater in the study area is imported from either northern California or the Colorado River, and both sources have an oxygen-18 and deuterium composition different from that of local surface water and groundwater (fig. 4). These data show that some groundwater samples contained as much as 70 percent imported water-water that presumably has a wastewater history. The percentage of wastewater in a sample was used to help interpret genetic and chemical data collected as part of this study.
Fecal indicator bacteria concentrations in water extractions from kelp and beach sands near Malibu, California, July 2009 to April 2010.

[kg, kilograms; MPN, Most Probable Number; ml, milliliters]

\begin{tabular}{|c|c|c|c|c|c|c|}
\hline \multirow[b]{2}{*}{ Sample } & \multirow[b]{2}{*}{ Date } & \multirow{2}{*}{$\begin{array}{c}\text { Mass of } \\
\text { sample, } \\
\text { in } \mathbf{k g}\end{array}$} & \multirow{2}{*}{$\begin{array}{c}\text { Mass of } \\
\text { extract- } \\
\text { ant, } \\
\text { in } \mathbf{~ k g}\end{array}$} & \multicolumn{3}{|c|}{$\begin{array}{l}\text { Fecal indicator bacteria, } \\
\text { in MPN per } 100 \mathrm{ml}\end{array}$} \\
\hline & & & & $\begin{array}{c}\text { Total } \\
\text { coliform }\end{array}$ & $\begin{array}{l}\text { Esch- } \\
\text { erichia } \\
\text { coli. }\end{array}$ & $\begin{array}{l}\text { Entero- } \\
\text { coccus }\end{array}$ \\
\hline Kelp & 07/24/2009 & 5.2 & 7.3 & 20,000 & 140 & 11,000 \\
\hline Kelp & 04/22/2009 & 21.3 & 12.6 & 2,800 & 330 & 2,100 \\
\hline Sand & $10 / 01 / 2009$ & 0.5 & 7.0 & 10 & 10 & 230 \\
\hline Sand & 04/22/2009 & 0.5 & 7.0 & 20 & 10 & 10 \\
\hline
\end{tabular}

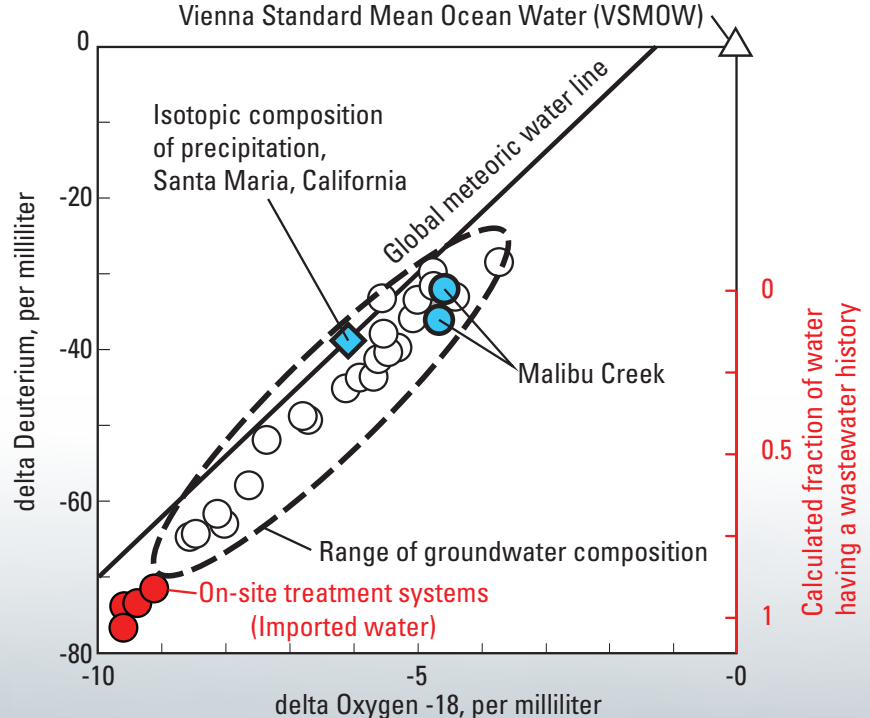

Figure 4. delta Oxygen-18, delta Deuterium, and percent wastewater in sampled wells, Malibu, California, July 2009 to April 2010.

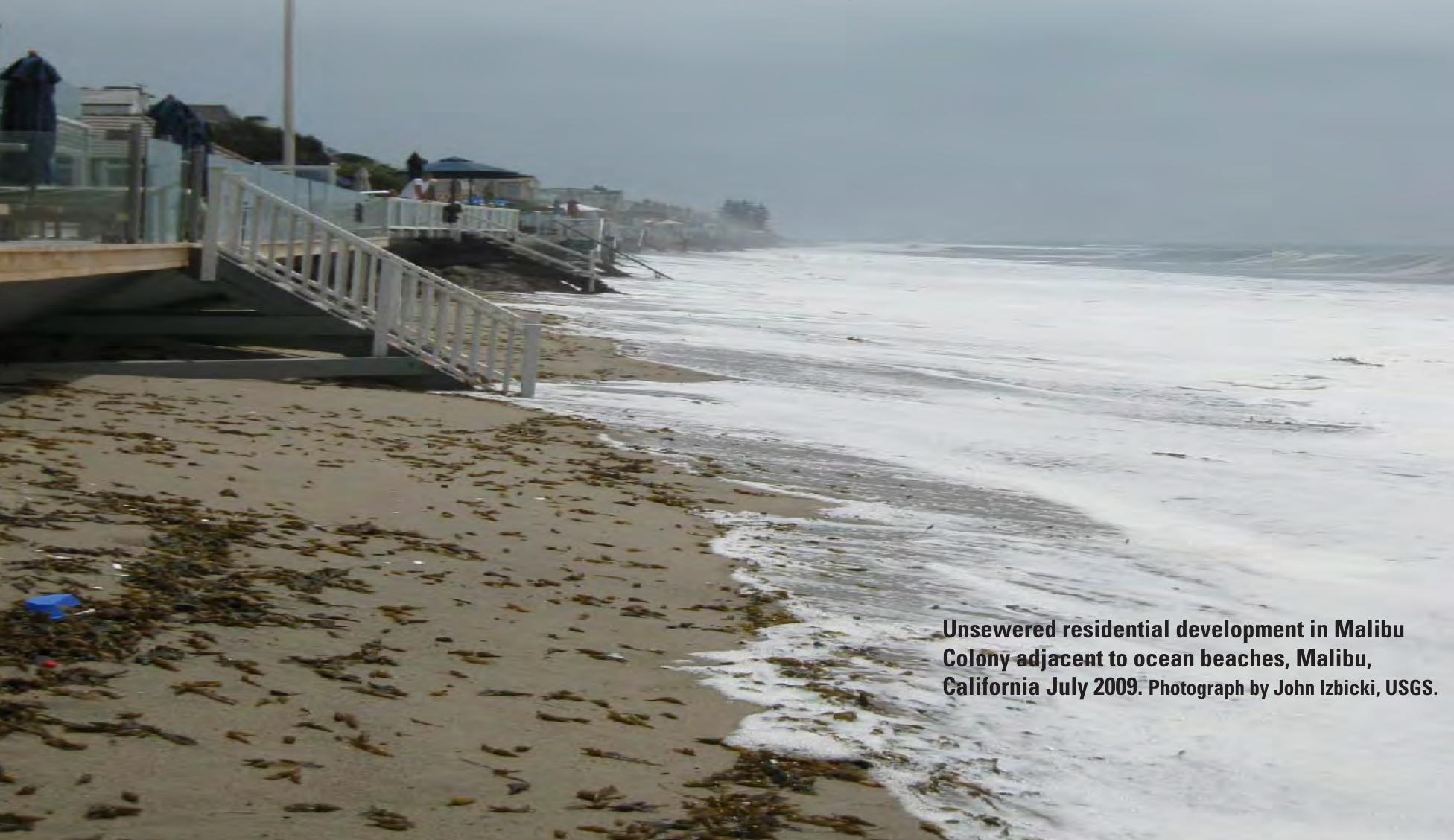


The naturally occurring radioactive isotope, radon-222, was used to evaluate contributions from the local groundwater system to Malibu Lagoon and the ocean. Radon-222 has high activity in groundwater and low activity in surface water. High radon-222 activities in surface water indicate contributions from groundwater discharge. Radon-222 activity was compared to FIB concentrations from Malibu Lagoon and the near-shore ocean to help determine if there was a relationship between groundwater discharge and FIB concentrations. For example, in November 2009, there were small increases in enterococcus concentrations in the near-shore ocean at low tide as water from Malibu Lagoon, which is high in Radon-222 because of groundwater discharge to the lagoon, moved through the sand berm separating the lagoon from the ocean (fig. 5). During the July sample period, enterococcus concentrations in the near-shore ocean at low tide were as high as $590 \mathrm{MPN}$ per $100 \mathrm{ml}$. In contrast, FIB concentrations remained below the detection limit at low tide, as radon-222 activity increased and groundwater discharged to the ocean adjacent to unsewered residential development in Malibu Colony (fig. 5).
Adjacent to Malibu Lagoon

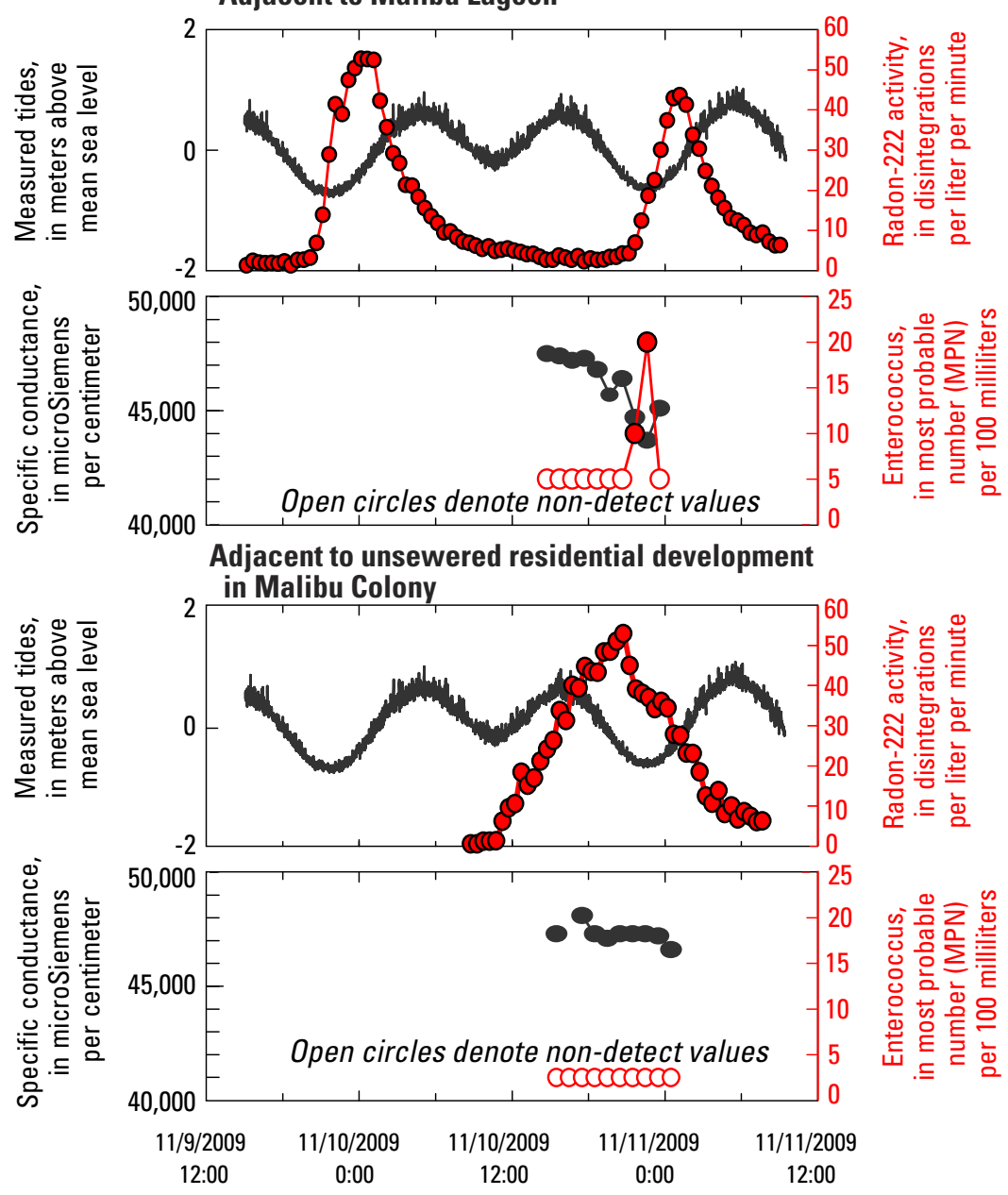

Figure 5. Tides, radon-222 activity, specific conductance, and enterococcus bacteria concentrations in the near-shore ocean adjacent to Malibu Lagoon and adjacent to unsewered residential development in Malibu Colony, Malibu, California, November 2009.
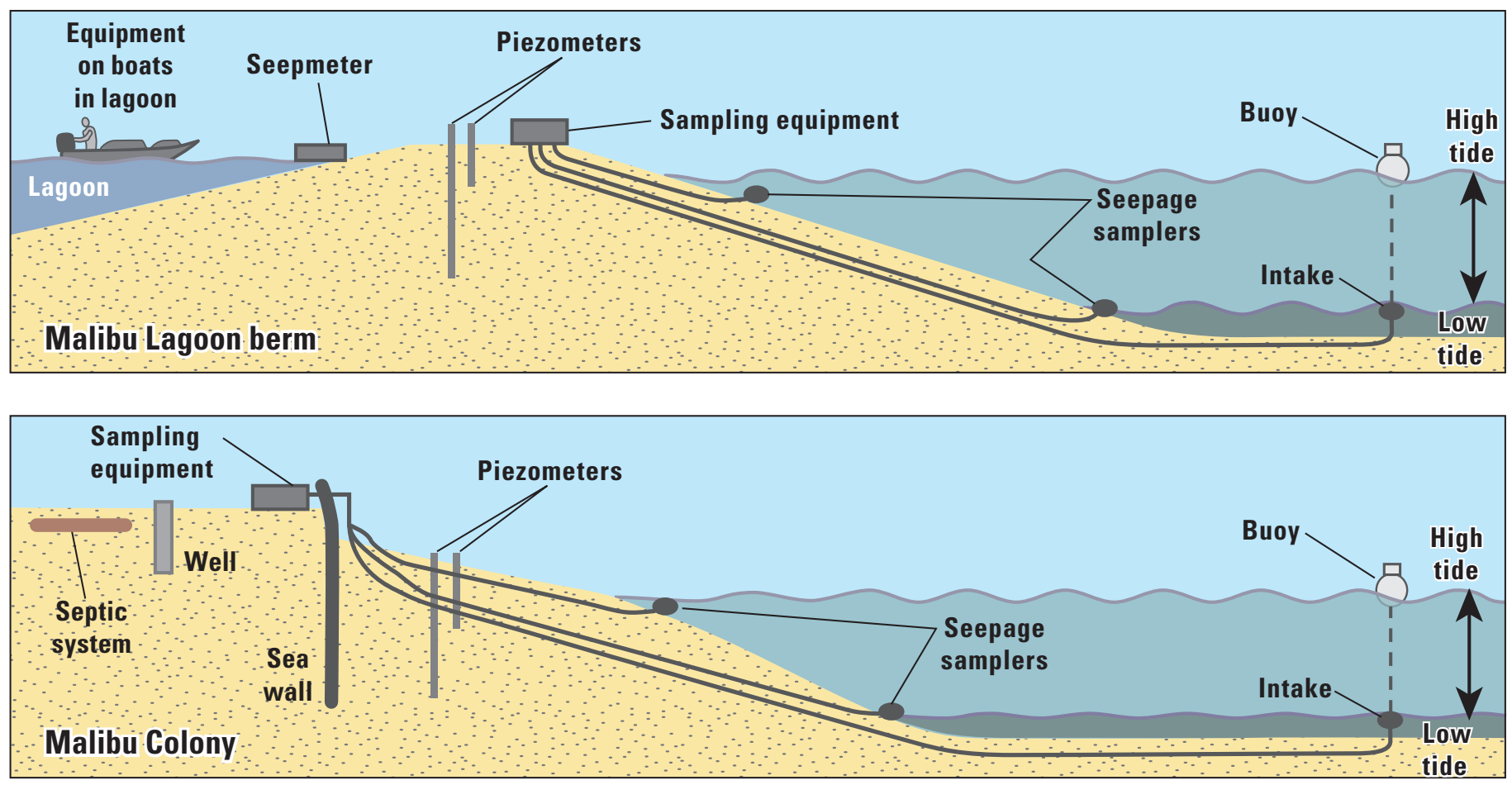

Diagrams of sample collection sites at the berm separating Malibu Lagoon from the ocean and adjacent to unsewered residential development in Malibu Colony. 


\section{Identifying Sources of Fecal Indicator Bacteria (FIB)}

A combination of genetic, molecular, and chemical techniques were used to identify the source of FIB in groundwater, Malibu Lagoon, and the near-shore ocean, under changing hydrologic conditions. Each of these techniques measures a different aspect of the microbiological community and of the possibility of fecal contamination. As such, they are not expected to produce the same results. More than 50 samples were analyzed for genetic, molecular, and chemical data. It is the combination of results from these multiple techniques and an understanding of the hydrology of the system that will produce the best interpretation of the sources of FIB in this sensitive environmental setting.

\section{Genetic Techniques}

Genetic techniques are based on the analysis of deoxyribonucleic acid (DNA) extracted from microorganisms in water samples and amplified to measurable concentrations by using Polymerase Chain Reaction (PCR). Genetic techniques used in this study included:

- Terminal-Restriction Fragment Length Polymorphism (T-RFLP): This technique uses restriction enzymes to cut DNA from different microorganisms into fragments of different size, known as amplicons. These fragments were used to evaluate the presence and absence of the microorganisms represented by those fragments. Interpretation of the T-RFLP data shows large differences in the microbial communities present in a sample collected from a conventional onsite wastewater treatment system and in a groundwater sample (well SMBRP-12) that had as much as 70 percent imported water (presumably having a wastewater history) as determined from the delta deuterium data (fig. 6). Only 7 percent of the measured amplicons, and the microorganisms they represent, were present in both samples. These data are consistent with the absence of FIB in groundwater and reflect the changes in the abundance and type of microorganism that would be expected from a combination of filtration, sorption, death, predation, and other factors. In contrast, as many as 30 percent of amplicons measured in samples from kelp and the near-shore ocean (fig. 6) were present in both the kelp and ocean samples-consistent with

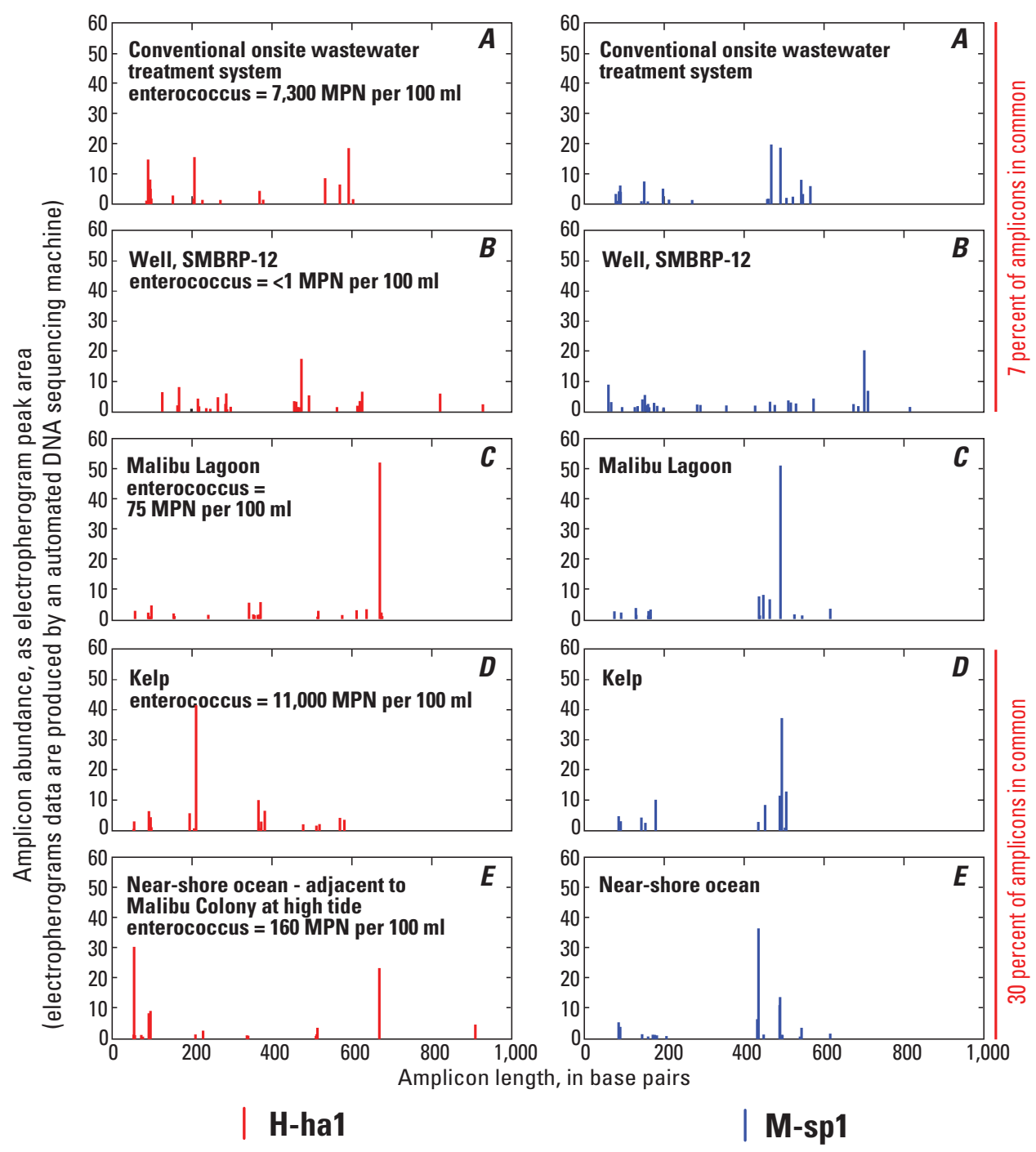

Restriction enzymes such as $\mathbf{H}$-ha1 and $\mathbf{M}$-sp1 are used to cut DNA from different microorganisms into fragments of different size, known as amplicons.

(Letter corresponds to locations of samples on figure 1.<, less than; MPN, Most Probable Number; ml, milliliter. Enterococus concentrations in Malibu lagoon vary daily, possibly as a result of photoinactivation of bacteria by ultraviolet radiation in sunlight.)

Figure 6. Amplicons from selected samples of wastewater, water from wells, Malibu Lagoon, the near-shore ocean, and extracts from kelp collected along the wrack line obtained using TerminalRestriction Length Fragment Polymorphism (T-RFLP) with H-ha1 and M-sp1 restriction enzymes, Malibu, California, July 2009.

possible contributions of FIB from kelp accumulated along the wrack line to the near-shore ocean at high tide. As the number of samples increases, multivariate statistical techniques, such as Principal Component Analysis (PCA), are needed to interpret these data.

- Microarray technology (Phylochip): This new technology uses more than 1 million genetic probes embedded onto a computer chip to identify as many as 50,000 different microorganisms. This technique can provide more information about the differences in microbial communities than T-RFLP data. Preliminary results show that a number of microbes commonly associated with human wastewater are absent in groundwater, Malibu Lagoon, and the near-shore ocean.

- Human-specific Bacteroidales: DNA from human-specific Bacteroidales, a microorganism associated with human fecal contamination, was used to evaluate the presence of human fecal contamination from onsite wastewater systems. Human-specific Bacteroidales were present at high numbers (as high as $10^{8}$ copies per liter) in onsite wastewater treatment systems. However, these microorganisms were not quantifiable or measurable (less than $10^{3}$ copies per liter) in water from wells, Malibu Lagoon, or in the nearshore ocean-suggesting that human fecal material is not present in samples from these areas. 


\section{Molecular Techniques}

Molecular techniques are based on the analysis of biochemical compounds, other than DNA, extracted from microorganisms in water samples. The analysis of phospholipid fatty acids (PLFAs) and fecal sterols (discussed under chemical techniques) were the molecular techniques used in this study. PLFAs provide energy, structural material for cellular membranes, and facilitate biochemical reactions during cellular metabolism. Unlike genetic material that can be used to identify specific microorganisms, the wide range of PLFAs present in a sample can be used to evaluate the biochemical processes in which microorganisms are engaged. PLFAs rapidly degrade after cell death, and are often more reflective of living (or recently living) microorganisms than genetic (DNA) techniques. Although discharges from onsite treatment systems have altered microbial processes and PLFA concentrations in groundwater, in the same manner as genetic techniques, additional statistical analysis is needed to interpret these data.

\section{Chemical Techniques}

Chemical data were used to find evidence of human wastewater in the environment. Sixty-nine organic compounds, collectively known as wastewater indicators, were analyzed. These included caffeine, fecal sterols (such as cholesterol), personal health-care products, and other compounds associated with human use. Chemical indicators of human wastewater were frequently detected in treated water from onsite wastewater treatment systems and from sampled wells having a high percent of treated wastewater estimated on the basis of delta deuterium data (fig. 7). Although cholesterol and other fecal sterol were commonly detected in these groundwater samples, most of these samples did not contain FIB. Where detected at low concentrations, FIBs were present in samples having a low percent of wastewater, as estimated on the basis of delta deuterium data (fig. 7), suggesting that although many wastewater compounds are transported through the
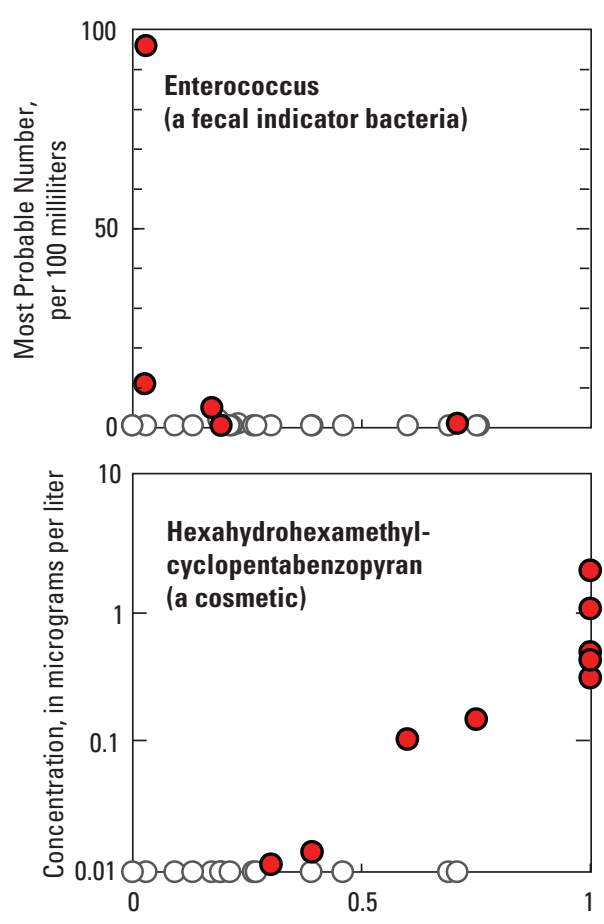

groundwater system, bacteria are removed as water travels through the porous media that compose the groundwater system. Man-made compounds, such as Bisphenol-A and cosmetics, that were present in onsite wastewater treatment systems and in groundwater having higher percentages of wastewater, were not present at detectable concentrations in Malibu Lagoon or the near-shore ocean.
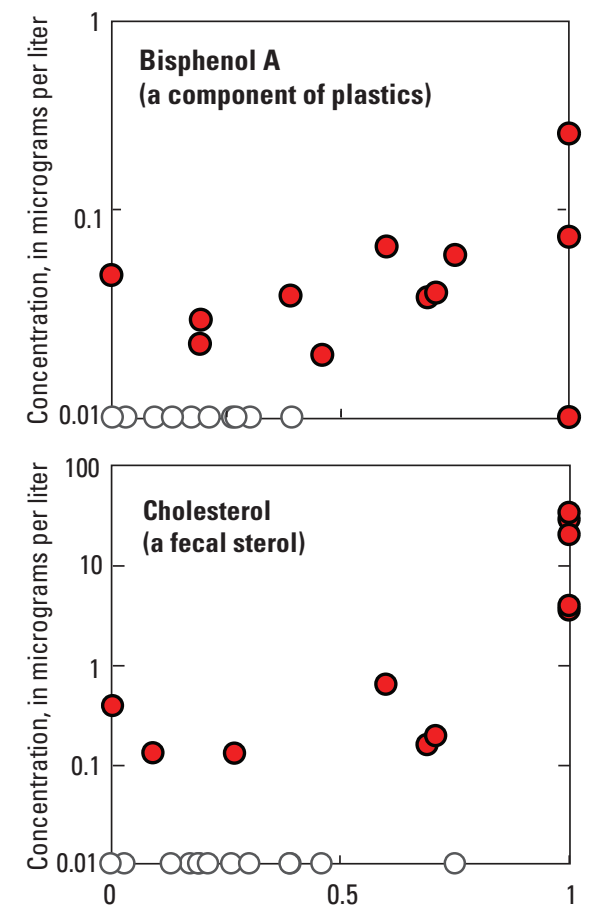

Fraction wastewater, estimated from delta Deuterium data

(Open circles denote non-detect values. Samples from onsite wastewater treatment systems are 100 percent wastewater. Enterococcus concentrations in onsite wastewater treatment systems are not shown because of high concentrations exceeding 240,000 most probable number (MPN) per 100 milliliters.)

Figure 7. Enterococcus, and selected wastewater-indicator compounds in water from wells as a function of percent wastewater (estimated from delta Deuterium data), Malibu, California, July 2009 to April 2010.

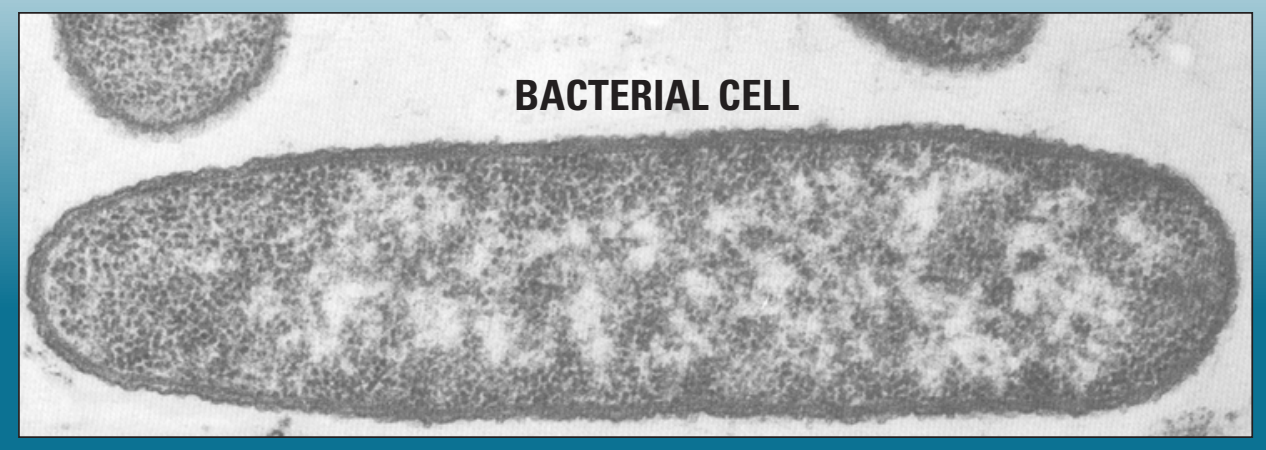

Diagram of bacterial cell wall showing phospholipid fatty acids 


\section{Preliminary Results}

Data collected for this study indicate that fecal indicator bacteria and humanspecific Bacteroides concentrations are high in samples from within onsite wastewater treatment systems; however, they are generally absent in samples from wells, even though many of the sampled wells contain water having a wastewater history. To reach sensitive receiving waters, such as Malibu Lagoon or the near-shore ocean, treated wastewater must first move through the underlying shallow groundwater. The absence of FIB is consistent with changes in the abundance and type of microorganisms indicated by preliminary analysis of genetic data that would be expected from a combination of filtration, sorption, death, predation, and other factors. The presence of FIB in kelp, and the similarity of genetic material from kelp and the near-shore ocean, suggests that the action of waves washing kelp that accumulated on beaches was a possible source of FIB to the near-shore ocean at high tide. Direct discharge from Malibu Lagoon to the ocean during the April sample period was a source of FIB to the ocean, and movement of water from the lagoon through the berm separating the lagoon from the ocean was a source of FIB to the near-shore ocean during the July sample period at low tide. However, data collected as part of this study need further interpretation before final conclusions can be drawn. In particular, statistical analysis of genetic data (T-RFLP, Phylochip), molecular data (PLFA), and chemical data needs to be completed to fully understand how these complex data sets relate to FIB occurrence and sources in this complex hydrologic setting.

\section{References Cited}

Izbicki, J.A., Swarzenski, P.W., Reich, C.D., Rollins, C., and Holden, P.A., 2009, Sources of fecal indicator bacteria in urban streams and ocean beaches, Santa Barbara, California. Annals of Environmental Science, Vol. 3, pp. 139-178. http:// iris.lib.neu.edu/cgi/viewcontent. cgi ?article $=1034 \&$ context $=$ aes

Regional Water Quality Control Board, 2009, Amendment to the water quality control plan for the coastal watersheds of Ventura and Los Angeles Counties to prohibit on-site wastewater disposal systems in the Malibu Civic Center Area: Resolution No. R4-2009-007. State of California Regional Water Quality Control Board (RWQCB), Los Angeles Region, Los Angeles, CA, 12 p., accessed at http://www.waterboards. ca.gov/board_info/agendas/2010/ sep/092110_4_att1.pdf on April 6, 2011
Surfer wading through discharge from Malibu Lagoon to the Pacific Ocean at Surfrider Beach (April 2010). Photograph by John Izbicki, USGS.
For more information contact: John Izbicki: Research Hydrologist, Project Chief U.S. Geological Survey, California Water Science Center 619-225-6131, jaizbick@usgs.gov http://ca.water.usgs.gov 